\title{
Helminth fauna of sympatric Przewalski's Equus przewalskii Poljakov, 1881 and domestic horses $E$. caballus $L$. in the Chernobyl exclusion zone, Ukraine
}

\author{
K. SLIVINSKA ${ }^{1}$, G. DVOJNOS ${ }^{1}$, G. KOPIJ ${ }^{2}$
}

\begin{abstract}
${ }^{1}$ Schmalhausen Institute of Zoology, National Academy of Sciences of the Ukraine, B. Khmelnitski Str.15, Kiev 30, MSP, Ukraine 01601, E-mail: kateryna@izan.kiev.ua; ${ }^{2}$ Department of Zoology \& Ecology, Agricultural University of Wroclaw, ul. Kozuchowska 5b, 51-630 Wroclaw, Poland, E-mail: kopij@ozi.ar.wroc.pl
\end{abstract}

\begin{abstract}
Summary
In 1998 Przewalski's horses have been introduced in the Chernobyl exclusion zone (CEZ), N Ukraine. They live in the zone under natural conditions. No anthelminthic treatment to these introduced horses has been applied to date. In this same area, 19 domestic horses were also stabled by some peasants. Eighteen years after the Chernobyl nuclear disaster, and five years after this introduction, the diagnostic dehelminthisation method has been applied both to the Przewalski's horses $(n=21)$ and the domestic horses $(n=$ 6). In addition, in one Przewalski's and one domestic horse helmith fauna was surveyed using the post-mortem method. A total of 29 and 19 helminth species has been recorded in the Przewalski's and domestic horses respectively. Only six helminth species were common for the two horse species compared. Species from the family Strongylidae constituted the dominant helminth group. Four cyathostomine species (Cyathostomum catinatum; Cylicostephanus minutus, C. longibursatus, Cylicocyclus nassatus) formed the majority of helminth parasites both in the Przewalski's and domestic horses. Our findings suggest that the CEZ has no effect on the species diversity of helminth fauna parasiting Przewalski's horses, neither it has an effect on the prevalence and intensity of parasite infestation. Behavioural and ecological studies also support the lack of such effect.
\end{abstract}

Key words: Equus przewalskii; Equus caballus; gastro-intestinal helminth fauna; Chernobyl

\section{Introduction}

After the Chernobyl nuclear disaster in 1986, an exclusion zone has been established for the re-naturalization of the polluted area around the disused nuclear plant. Since 1986, so called long-fallow lands has appeared in abandoned farmlands in this zone. Each year grasses thriving in these long-fallow lands, produce enormous biomass which is only partly consumed by large herbivores. To solve this ecological problem, grazing by horses in this area has been proposed (program "Fauna", 1998), as in comparison with other large herbivore mammals, horses are the most efficient grass consumers (Zharkikh et al., 2002). Therefore, 21 Przewalski's horses Equus przewalskii from the Askania Nova Biosphere Reserve, south Ukraine, have been introduced in the CEZ, 1998. The Przewalski's horse is included in the IUCN Red Data Book as an endangered species (Baillie \& Groombridge 1996). Parasitic fauna is one of the factors which may influence the mortality rate in this species. It is, therefore, especially important to investigate parasite diversity, and prevalence and intensity of parasite infestation in free-living animals. To date, little is known about the helminth fauna of Przewalski's horses. This fauna has only been investigated in Przewalski's horses living under zoo conditions in Prague (Baruš, 1962 a,b, 1962-63) and in Askania Nova (Dvojnos \& Zvegintsova, 1990; Dvojnos \& Kcharchenko,1994), but nothing is known about helminth parasites of the Przewalski's horse living under natural conditions. Just before the introduction, for all Przewalski's horses anthelminthic treatment has been applied. It was therefore interesting to investigate the fauna six years after. In this study, we surveyed helmith fauna of the Przewalski's horses living under natural conditions and we compare the helmith fauna of the Przewalski's horse and domestic horse living in this same area and in the same time.

\section{Study area}

The Chernobyl exclusion zone (CEZ) is located c. $200 \mathrm{~km}$ $\mathrm{N}$ of Kiev (lat. $51^{\circ} 16 \mathrm{~min} .41 \mathrm{sec}$; ) long. $30^{\circ} 13 \mathrm{~min} .24$ sec.), $123 \mathrm{~m}$ above sea level. This zone covers an area of $2070 \mathrm{~km}^{2}$, and falls entirely within the Polesie Lowland, Russian Plain. Climate of the CEZ is humid, with relatively mild winter and warm summers. The mean annual temperature is $5-7^{\circ} \mathrm{C}$. The mean temperature in July is $18^{\circ} \mathrm{C}$ $\left(\max .32^{\circ} \mathrm{C}\right)$, while in January $-6.1^{\circ} \mathrm{C}\left(\min .-25^{\circ} \mathrm{C}\right)$. The annual precipitation ranges from 550 to $750 \mathrm{~mm}$. The snow cover lasts on average c. 50 days per year. The mean depth of the snow cover is $12-13 \mathrm{~cm}$. 
The CEZ is fenced with metal nets. Along with c. 100 peasants still living in the CEZ, only a few other man have constant access to this area. Before the nuclear disaster, the CEZ consisted farmlands with forest fragments. At present, c. $60 \%$ of the area is covered with forests (50\% of which is pine forest) and the remaining consists of abandoned arable grounds, meadows, pastures and human settlements.

\section{Material and Methods}

Przewalski's horses have lived under natural conditions in the CEZ since 1998. In 2004, there were 67 horses in three reproductive groups. No anthelminthic treatment to these animals has been applied to date. In this same area, 19 domestic horses were also stabled by some peasants.

There were three reproductive groups of the Przewalski's horse in February 2004. The largest group has been selected for the helminth survey. The group was composed of one stallion (16 years old), and nine mares ( $6-12$ years old) and eleven their offspring ( $1-2$ years old). In March 2004, out of 19 domestic horses, six ones (two stallions, 9 - 10 years old; four mares, $4-10$ years old) have been randomly selected for the helminth survey. In addition, a post-morten survey has been performed on Przewalski's horse stallion (9 years old) kept in captivity, and on domestic horse stallion ( 3 year old) from the CEZ. For the partial helminthological section the method described by Kotelnikov (1984) has been used. Out of 19 domestic horses stabled, six were selected for helminth survey.

The diagnostic dehelminthisation has been applied. Horses were treated as one unit with the Univerm (Aversektin C $0.2 \%$, Farmbiomed, Moscow, Russia) in dose $50 \mathrm{mg}$ for 1 $\mathrm{kg}$ of animal. Since the individuals were treated as one unit the Univerm dose was doubled. An assumption has been made that the body weight of one individual was c. $300 \mathrm{~kg}$, thus the total body weight of 21 individuals was c. 6000 $\mathrm{kg}$. Therefore a total of $600 \mathrm{~g}$ of the Univerm was used for the whole anthelminthic treatment. The anthelmintic prepa-

Table 1. Results of parasitic survey in Przewalski's horses (Equus przewalskii), $\mathrm{n}=21$, in the Chernobyl exclusion zone

\begin{tabular}{|c|c|c|c|c|c|}
\hline \multirow{2}{*}{ Species } & \multirow{2}{*}{$\begin{array}{c}\text { Prevalence } \\
\%\end{array}$} & \multicolumn{4}{|c|}{ Intensity } \\
\hline & & Min & Max & Mean & SE \\
\hline \multicolumn{6}{|l|}{ Gasterophilidae } \\
\hline Gasterophilus intestinalis & 47.6 & 1 & 7 & 2.7 & 0.33 \\
\hline G. veterinus & 9.5 & 1 & 1 & 1.0 & 0.05 \\
\hline \multicolumn{6}{|l|}{ Anoplocephalidae } \\
\hline Anoplocephala perfoliata & 14.3 & 1 & 2 & 1.7 & 0.10 \\
\hline Parascaris equorum & 19.0 & 1 & 2 & 1.3 & 0.09 \\
\hline Oxyuris equi & 81.0 & 1 & 30 & 11.4 & 1.71 \\
\hline S. edentatus & 14.3 & 1 & 3 & 2.0 & 0.16 \\
\hline S. vulgaris & 33.3 & 2 & 8 & 5.0 & 0.48 \\
\hline Triodontophorus serratus & 19.0 & 1 & 2 & 1.5 & 0.17 \\
\hline T. brevicauda & 4.8 & 1 & 1 & 1.0 & 0.03 \\
\hline T. tenuicollis & 33.3 & 1 & 2 & 1.3 & 0.11 \\
\hline Craterostomum acuticaudatum & 42.9 & 1 & 8 & 3.3 & 0.41 \\
\hline Cyathostomum catinatum & 95.2 & 8 & 125 & 82.2 & 6.00 \\
\hline Coronocyclus coronatus & 81.0 & 1 & 16 & 5.1 & 0.89 \\
\hline C. labiatus & 33.3 & 1 & 8 & 3.0 & 0.36 \\
\hline C. labratus & 33.3 & 1 & 3 & 1.7 & 0.17 \\
\hline Cylicostephanus calicatus & 90.5 & 1 & 13 & 4.4 & 0.64 \\
\hline C. minutus & 100 & 1 & 114 & 38.0 & 6.15 \\
\hline C. longibursatus & 100 & 1 & 81 & 15.8 & 3.83 \\
\hline C. goldi & 76.2 & 1 & 13 & 4.0 & 0.73 \\
\hline C. bidentatus & 90.57 & 1 & 42 & 11.5 & 2.41 \\
\hline C. insigne & 42.9 & 1 & 19 & 7.8 & 1.04 \\
\hline C. leptostomus & 71.4 & 1 & 22 & 3.5 & 1.73 \\
\hline C. nassatus & 95.2 & 5 & 125 & 32.7 & 5.68 \\
\hline C. ashworthi & 90.5 & 1 & 40 & 11.5 & 2.72 \\
\hline C. ultrajectinus & 28.6 & 3 & 11 & 7.0 & 0.65 \\
\hline P. poculatum & 9.5 & 1 & 1 & 1.0 & 0.05 \\
\hline Cylicodontophorus bicoronatus & 23.8 & 1 & 6 & 2.2 & 0.23 \\
\hline C. euproctus & 47.6 & 1 & 8 & 3.6 & 0.45 \\
\hline C. mettami & 14.3 & 1 & 3 & 1.7 & 0.12 \\
\hline Poteriostomum ratzii & 9.5 & 1 & 1 & 1.0 & 0.06 \\
\hline Gyalocephalus capitatus & 33.3 & 1 & 4 & 2.28 & 0.22 \\
\hline
\end{tabular}


ration was mixed with the oats. From the second to the seventh post-treatment day, faeces were collected from the pasture, and preserved in $40 \%$ alcohol. In the laboratory, helminth isolated from the faeces, were fixed in $70 \%$ alcohol, counted and identified down to species level, using keys after Lichtenfels (1975) and Dvojnos \& Kharchenko (1994).

All Przewalski's and domestic horses which helminth fauna was surveyed had been individually recognised in the field. Each horse was observed in the field till it defecated, what allowed to collect faeces individually form eight horses each day within five-day-period, while in the same time faeces from the remaining 13 horses, were only collected once. A total of 4729 helminth specimens were isolated and all were identified down to the species level.

Faeces from domestic horses were collected on a daily basis within the five-day-survey. A total of 5000 helminth specimens were isolated, but only $20 \%$ of them (900 specimens), randomly selected, were identified down to the species level.

\section{Results}

Helminthes were recorded in all 21 Przewalski's horses surveyed. The helminth fauna comprised 29 species represented by three nematode (Strongylidae, Oxyuridae, Ascaridae) and one cestode family (Anoplocephalida). The nematode family Strongylidae was represented by 26 species belonging to the subfamily Strongylinae (six species) and Cyathostominae (20 species). The prevalence of the strongylid infestation was $100 \%$. Cylicostephanus minutus, $C$. longibursatus, Cyathostomum catinatum, Cylicocyclus nassatus, C. calicatus, C. asworthi, Cylicotetrapedon bidentatus occurred in more than 19 Przewalski's horses (90 $\%$ ) surveyed. Coronocyclus coronatus, Cylicostephanus goldi and C. leptostomus occurred in $70-81 \%$, and the remaining 17 species occurred in less than $50 \%$ of all Przewalski's horses surveyed (Table 1). Oxyuris equi from the family Oxyuridae was recorded in $81 \%$, while Parascaris equorum, from the family Ascaridae, in $19 \%$ of Przewalski's horses surveyed.

In general the intensity of nematode infestation was low. The mean number of specimens of a given species from the subfamily Strongylinae varied from 1.0 to 3.3 (Table 1), while that from the subfamily Cyathostominae varied from 1.0 to 88.2 . The mean number of oxyurid specimens per horse was 11.4, while that of ascarid specimens 1.3 (Table 1). Cyathostomum catinatum was by far the most

Table 2. Results of the post-mortem helminth survey of Przewalski's horse kept in captivity in the Chernobyl exclusion zone

\begin{tabular}{lcc}
\hline \multicolumn{1}{c}{ Species } & $\begin{array}{c}\text { Number of } \\
\text { individuals }\end{array}$ & $\%$ \\
\hline Strongylus edentatus & 2 & 0.8 \\
S. vulgaris & 4 & 1.6 \\
Triodontophorus serratus & 1 & 0.4 \\
T. tenuicollis & 13 & 5.1 \\
Craterostomum acuticaudatum & 6 & 2.3 \\
Cyathostomum catinatum & 83 & 32.3 \\
Cylicostephanus minutus & 15 & 5.8 \\
C.longibursatus & 71 & 27.6 \\
C.goldi & 4 & 1.6 \\
Cylicotetrapedon bidentatus & 4 & 1.6 \\
Cylicocyclus nassatus & 25 & 9.7 \\
Cylicodontophorus bicoronatus & 14 & 5.4 \\
C.mettami & 2 & 0.8 \\
P.imparidentatum & 7 & 2.7 \\
Gyalocephalus capitatus & 4 & 1.6 \\
Total & 257 & 100 \\
\hline
\end{tabular}

Table 3. Results of helminth survey in domestic horses (Equus caballus), $\mathrm{n}=6$, in the Chernobyl exclusion zone

\begin{tabular}{|c|c|c|c|c|c|}
\hline \multirow{2}{*}{ Species } & \multirow{2}{*}{$\begin{array}{c}\text { Prevalence } \\
\%\end{array}$} & \multicolumn{4}{|c|}{ Mean intensity } \\
\hline & & Min & Max & Mean & $\pm \mathrm{SE}$ \\
\hline Strongylus edentatus & 16.6 & 3 & 3 & 3 & 0.50 \\
\hline Triodontophorus serratus & 16.6 & 4 & 4 & 4 & 0.66 \\
\hline Cyathostomum catinatum & 100 & 18 & 76 & 36 & 8.55 \\
\hline Coronocyclus coronatus & 66.6 & 1 & 4 & 2 & 0.61 \\
\hline C. labiatus & 33.3 & 1 & 2 & 1.5 & 0.34 \\
\hline Cylicostephanus calicatus & 100 & 3 & 7 & 0.2 & 1.11 \\
\hline C. minutus & 100 & 2 & 46 & 28.2 & 8.15 \\
\hline C. longyibursatus & 100 & 8 & 54 & 23.2 & 7.95 \\
\hline C. goldi & 50 & 2 & 12 & 6 & 1.91 \\
\hline Cylicotetrapedon bidentatus & 16.6 & 1 & 1 & 1 & 0.16 \\
\hline Cylicocyclus insigne & 33.3 & 1 & 1 & 1 & 0.21 \\
\hline C. leptostomus & 66.6 & 3 & 41 & 14.3 & 6.41 \\
\hline C. nassatus & 100 & 5 & 46 & 26.2 & 6.42 \\
\hline C. ashworthi & 100 & 3 & 57 & 14.3 & 8.57 \\
\hline C. ultrajectinus & 16.6 & 5 & 5 & 5 & 0.83 \\
\hline Cylicodontophorus mettami & 16.6 & 1 & 1 & 1 & 0.16 \\
\hline Poteriostomum ratzii & 16.6 & 1 & 1 & 1 & 0.16 \\
\hline Gyalocephalus capitatus & 50 & 1 & 2 & 1.3 & 0.33 \\
\hline
\end{tabular}


Table 4. Parasitic fauna of the dissected domestic horse in the Chernobyl exclusion zone

\begin{tabular}{lcc}
\hline Species & $\begin{array}{c}\text { Number of } \\
\text { individuals }\end{array}$ & $\%$ \\
\hline Strongylus vulgaris & 9 & 2.82 \\
S. edentatus & 3 & 0.94 \\
Triodontophorus serratus & 2 & 0.62 \\
T. brevicauda & 2 & 0.62 \\
Craterostomum acuticaudatum & 1 & 0.31 \\
Gyalocephalus capitatus & 1 & 0.31 \\
Coronocyclus coronatus & 1 & 0.31 \\
Cyathostomum catinatum & 7 & 2.19 \\
Cylicodontophorus bicoronatus & 1 & 0.31 \\
Cylicostephanus calicatus & 1 & 0.31 \\
C.minutus & 65 & 20.37 \\
C. longibursatus & 1 & 0.31 \\
C. goldi & 3 & 0.94 \\
Petrovinema poculatum & 1 & 0.31 \\
Cylicocyclus elongatus & 160 & 50.15 \\
C. insigne & 6 & 1.88 \\
C. nassatus & 45 & 14.10 \\
C. ashworthi & 1 & 0.31 \\
Oxyuris equi & 8 & 2.50 \\
Gasterophilus intestinalis & 1 & 0.31 \\
Total & 319 & 100 \\
\hline
\end{tabular}

abundant nematode species (Table 1). The mean number of specimens of Cylicostephanus minutus and Cylicocyclus nassatus per horse was 38 and 33 respectively. The mean number of specimens of the remaining 22 strongylid species was less than 15 (Table 1).

Other helminth families were represented by single species only (Table1).

Tapeworms were only recorded in $14.3 \%$ of Przewalski's horses surveyed. The number of tapeworms per horse ranged from 1 to $2(\mathrm{x}=1.6)$.

Two non-helminth gastro-intestinal parasites, namely the larvae of Gasterophilus intestinalis and G. veterinus (Diptera: Gasterophilidae) were also recorded. The prevalence of $G$. intestinalis was $47.6 \%$, while that of $G$. veterinus $9.5 \%$. The number of $G$. intestinalis specimens per horse ranged from 1 to $7(\mathrm{x}=2.7)$, while only single specimens of $G$. veterinus were recorded in each horse species.

In one Przewalski's horse kept in captivity, 15 nematode species were recorded. All belonged to the family Strongylidae (Table 2). The most abundant species were Cyathostomum catinatum, Cylicostephanus longibursatus and $C y$ licocyclus nassatus. They formed together $69.6 \%$ all nematode species recorded (Table 2).

Helminthes were recorded in all six domestic horses surveyed. The helminth fauna was represented by 18 species, all from the family Strongylidae. The subfamily Strongylinae included Strongylus edentatus and Triodontophorus serratus. These species were recorded in single horses and were represented by a few specimens only (Table 3). The subfamily Cyathostominae included 16 species. Six of these species, namely Cyathostomum catinatum, Cylicostephanus minutus, C. longibursatus, C. calicatus, Cylico- cyclus nassatus and C. ashworthi were recorded in all horses surveyed. Six other nematode species were recorded in $33-67 \%$ of horses, while four remaining species, in single horses only (Table 3). Nematode species with the highest prevalence of infestation (100\%) had also the highest intensity of infestation (the number of specimens per horse), except for Cylicostephanus calicatus (Table 3). The most abundant nematode species was Cyathostomum catinatum. The number of specimens of this species per horse ranged from 18 to $76(\mathrm{x}=36)$. In four other nematode species, the mean number of specimens per horse ranged from 14.3 to 28.2 (Table 3 ).

In the dissected domestic horse, 19 helminth species (18 from the family Strongylidae and one from the family Oxyuridae) were recorded (Table 4). Cylicocyclus elongatus, C. nassatus and Cylicostephanus minutus comprised $84.0 \%$ of all nematode species recorded (Table 4). A single specimen of Gasterophilus intestinalis (Diptera: Gasterophilidae) was also recorded.

\section{Discussion}

A total of 31 helminth species were recorded in both horse species surveyed in the CEZ. While a total of 31 helminth species were recorded in the free-living Przewalski's horses, only 15 such species were recorded in Przewalski's horse living under zoo conditions. In herd domestic horse 19 , while in stabled horses 18 helminth species were recorded. It appears therefore that higher helminth diversity in both horse species surveyed prevails in herds than in stabled horses. On the other hand, the intensity of helminth infestation appears to be higher in the stabled than in the free-living horses. Such results could, however, be biased by difference in sample sizes (see 'Material and Methods'). A total of 30 helminth species were recorded from Przewalski's horse from the CEZ (this study) in comparison with 39 such species recorded in Askania Nova, S Ukraine (Dvojnos \& Zvegintsova, 1990). Such difference could have been caused by different method of helminth survey, as post-morten survey gives more accurate picture of helminth fauna than the survey by the mean of the diagnostic dehelmintization. In the CEZ, summer is much colder than in Askania Nova and therefore not suitable for the larval development of some nematode species (Trach, 1982). Small horse populations surveyed in the new area may also influence the low number of parasite species.

In both horses species, the dominant helminth group (both in terms of prevalence and intensity of infestation) both in the CEZ and Askania Nova was the family Strongylidae. Most Przewalski's horses surveyed were infested by Oxyuris equi (Oxyuridae). In addition, Anoplocephala perfoliata (Cestoda: Anoplocephalidae) and Gasterophilus intestinalis (Diptera: Gasterophilidae) were recorded in Przewalski's horses in both areas compared. It is important to point out that Cylicotetrapedon bidentatus (Strongylidae: Cyathostominae) was recorded in $90.5 \%$ of Przewalski's horses in the CEZ, while only $6.3 \%$ of Przewalski's horses were infested by this nematode species in Askania Nova. 
Also, Cylicocyclus ultrajectinus (Strongylidae: Cyathostominae) infested Przewalski's horses more often in the CEZ (30.6\%) than in Askania Nova (6.3\%).

Nematode species such as Strongylus equinus, Triodontophorus nipponicus, Cyathostomum pateratum, Coronocyclus sagittatus, Cylicostephanus hybridus, Cylicotetrapedon asymmetricus, Cylicocyclus radiatus, C. elongatus and Probstmayria vivipara were recorded in Askania Nova with the prevalence 6.3 - $43.8 \%$ (Dvojnos et al., 1990), but were not recorded in the CEZ. This could have been a result of different method applied. In the present study, diagnostic dehelminthisantion, while in other studies postmortem methods have been applied. Also the fact that not all faeces were collected in the CEZ could have slightly underestimate the number of nematode species recorded. Before the introduction into the CEZ, for all Przewalski's horses anthelminthic treatment has been applied (Zharkikh et al., 2002). Some helminth species could have been, therefore, eliminated from all these horses and their offspring surveyed in the CEZ.

Our findings that a few strongylid cyathostome species constitute the bulk of the nematode population in the Przewalski's horse are confirmed by results of helminth surveys conducted on other horse species, viz. tarpans Equus gmelini Antonius, 1912 in Poland (Romaniuk et al., 1983; 2001; Gawor, 2000), in France (Marchand et al., 2004), Turkmen kulans Equus hemionus Pallas, 1775 in the Ukraine and Turkmenia (Dvojnos et al., 1992) and various breeds of domestic horses in different parts of the world (Mfitilodze \& Hutchinson 1985, 1990; Reinemeyer et al., 1984; Lyons et al. 1997; Scialdo-Krecek et al., 1983; Ogbourne 1976; Eysker \& Mirck, 1986; Meana et al., 2004; Farkas, 2004).

Our findings suggest that the CEZ has no effect on the species diversity of helminth fauna parasiting Przewalski's horses, neither it has an effect on the prevalence and intensity of parasite infestation. Behavioural and ecological studies also support the lack of such effect. The CEZ horse population is in increase, biological and behavioural features are typical for this species (own data). Among all 29 helminth species recorded only Strongylus vulgaris is of veterinary importance. It may become however harmful only if reaches high intensity. At least under CEZ conditions, anthelminthic treatment is not necessary.

\section{Acknowledgements}

We would like to thank Alexander Borovskij, Alexander Starovir for help in collected the field data; Nikolaj Narolskij for help in addition to computerizing some of the data.

\section{References}

BAillie, J., Groombridge, B. (Eds.) (1996): IUCN Red List of Threatened Animals. IUCN, Glad, Switzerland and Cambridge, UK

BARUŠ, V. (1962a): Helminthfauna of horses in Czecho- slovakia. Čsl. Parasitol.: 9: 15 - 94 (in Czech)

BARUŠ, V. (1962b): Further knowledge on the helminthofauna of the Przewalsky Horse (Equus przewalskii Poliakov 1881). Zool. Listy, 11: 380 - 381 (in Czech)

BARUŠ, V. (1962 - 63): Parasitic worms of horses in Czechoslovakia. Helmithologia, 4: 59 - 66 (in German).

Dvojnos, G. M., Zvegintsova, N. S. (1990): The ecological and parastiological characteristic of Przewalski horse in Askania-Nova. Proceed. of the $5^{\text {th }}$ Intern. Sympos. on the preservation of the Przewalski horse, Leipzig: $164-$ 163

Dvojnos, G. M., KCHARCHENKO, V. A. (1994): The strongylid of domestic and wild horses. Kiev. "Naukova dumka", 233 p. (in Russian)

Dvojnos, G. M., KCHARChEnKo, V. A., Zvegintsova, N. S. (1992): Characteristics of the helminth community from Turkmen kulan, Equus hemionus). Parasitologia, 26: 246 - 251 (in Russian)

EYSKER, M., MIRCK, M. H. (1986): The distribution of inhibited early third stage Cyathostominae larvae in the large intestine of the horse. Zeitschr. Parasiten, 72: 815 - 820

FARKAS, R. (2004): The prevalence of equine gastrointestinal parasites in Hungary. Proceedings the IX European multicolloquium of parasitology 18 - 23 July: 463 - 464

GAWOR, J. (2000): Occurrence of Strongylidae (Nematoda: Strongyloidea) in Polish horses "Tarpans" from Popielno reserve. Wiad. parazytol., 46: 87 - 92

Kotelnikov, G. A. (1984): Helminthological investigated of animal and area. Moscow. "Kolos", 238 (in Russian)

LiCHTENFELS, J. R. (1975): Helminths of domestic equids. Proc. Helminthol. Soc. Washington, 42: 92

LyOns, E. T., Tolliver, S. C., Collins, S. S., Drudge, J. H., Granstrom, D. E. (1997): Transmission of some species of internal parasites in horses born in 1993, 1994 and 1995 on the same pasture on a farm in central Kentucky. Vet. Parasitol, 70: $225-240$

Marchand, A., Le GoËc, F., Bourdeau, P. J. (2004): Digestive nematodes in donkeys in France and their control with ivermectin. Proceedings the IX European multicolloquium of parasitology $18-23$ July, p. 354

Meana, A., Olmeda, A.S., Pato, N.F., Diez, E., FeliPe, M., MotA, J. (2004): Prevalence of mayor parasitic infections in free-ranging horses at Donana (Spain). Proceedings the IX European multicolloquium of parasitology 18 - 23 July, p. 463

Mfitilodze, M.W., Hutchinson, G. W. (1985): The site distribution of adult strongyle parasites in the large intestines of horses in Australia. Int. J. Parasitol., 15: 313 319

Mfitilodze, M. W., Hutchinson, G. W. (1990): Prevalence and abundance of equine strongyles (Nematoda: Strongyloidea) in tropical Australia. J. Parasitol., 4: 487 494

OgBourne, C. P. (1976): The prevalence, relative abundance and the site distribution of nematodes of the subfamily Cyathostominae in horses killed in Britain. J. Helminthol., 50: $203-214$

Reinemeyer, C. R., Smith, S. A., Gabel, A. A., Herd, R. 
P. (1984): The prevalence and intensity of internal parasites of horses in the USA. Vet. Parasitol., 15: $75-83$ ROMANiUK, K., BUGAJAK, P., LAWRYNOWICZ, Z. (1983): Internal parasitic infections of the free-living and kept indoor primitive Polish horses. Wiad. Parazytol., 3: $325-$ 333

RomaniUK, K., JAWORSKI, Z., SNARSKA, A. (2001): The existence of internal parasites in the primitive Polish horses from forest breeding. Med. Wet., 57: 204 - 206 (in Polish)

Scialdo-KreceK, R. C., Reinecke, R. K., Biggs, H. C. (1983): Studies on the parasites of zebras III. Nematodes of

RECEIVED JUNE 16, 2005 the Mountain zebra from the farm "Kelpie" and the Namib-Naukluft Park, South West Africa/Namibia. Onderstepoort J. Vet. Res., 50: $283-290$

TRACH, V. N. (1982) The parasitical strongylid larvae of domestic ruminant. Kiev: "Naukova dumka", 128 p. (in Russian)

ZhARKIKH, T. L., YASYNETSKA, N. I., BorovsKiJ, A. N., Zvegintsova, N. S. (2002): A study of the Przewalski horse population in the zone of Chernobyl Nuclear Power Plant. Bulleten Moskovskogo obschestva ispitatelej prirodi. Otdelenie biologii, 107: 9 - 16 (in Russian) 